\title{
Emerging Innovative Teaching Strategies in Nursing
}

\author{
Rajesh Kumar Sharma* \\ Swami Rama Himalayan University, India
}

Submission: March 08, 2017; Published: April 21, 2017

*Corresponding author: Rajesh Kumar Sharma, Assistant Professor, Himalayan College of Nursing, Swami Rama Himalayan University, Dehradun, Uttrakhand, India, Email: rajeshsharma.hcn@gmail.com

\section{Introduction}

Education is a light which shows the right direction to mankind to surge. The purpose of education is not just making a student literate but also adds rationale thinking, knowledgeably and self sufficiency [1]. Nursing is a field which requiring clinical knowledge \& skills to care for the patients \& his family as we deal and handle with real life situations [2]. Nursing graduates must be prepared to practice as competent healthcare professionals in a highly complex, diverse, and ever-changing environment. The learning process in nursing is very unique because nursing student should be able to perform the activities of the profession in live situations. Critical thinking is crucial to providing safe, competent, and skillful nursing practice [3]. During any course of nursing, clinical experience considered as lifeblood of nursing education. Nurse educators and faculties have a responsibility to provide most efficient clinical instruction to aid best learning to nursing students during their course.

Nurse educators are obligated to create learning environments that support critical thinking. Not only it is important what students learn, but also equally important that how they learn [4]. Traditional teaching methods should be transformed to improve learning experiences and facilitate lifelong learning. Teaching strategies that involve experience by "doing" and dialogue with "others" will promote more significant learning. Creativity can be developed and innovation benefits both students and teachers.

A teacher tries his best to impart knowledge as the way he understood it. So, any communication methods that serve this purpose without destroying the objective could be considered as innovative methods of teaching. The use of innovative methods in health care institutions has the potential not only to improve education, but also to empower people, strengthen governance and galvanize the effort to achieve the human development goal for the country [5]. A study by Mary [6] suggest that use of more creative methodologies like utilizing web based teaching, portfolios, case studies and a range of other creative teaching strategies in teaching enhance the competencies rather than predominantly using didactic teaching methods such as the lecture method and demonstration to teach across all subject areas.

Innovation is the act of constructive thinking, grouping knowledge, skills, and attitude into new, original \& rational ideas.

Critical thinking Imagination Plan Action Achieve objectives

Critical thinking $\Rightarrow$ Imagination $\Rightarrow$ Plan $\Rightarrow$ Action

$\Rightarrow$ Achieve objectives

\section{Emerging Trends in Teaching Methodology}

There are various Instruction strategies for classroom \& clinical are Lecture, discussion, demonstration, simulation, laboratory, seminar, panel, symposium, problem solving, problem based learning (PBL), workshop, project, role- play (socio drama), clinical teaching methods, case based learning, clinical simulation, programmed instruction, self directed learning(SDL), micro teaching, computer assisted instruction (CAI), computer assisted learning (CAL), blackboard learning (Web based learning), Mind mapping/Concept mapping, Storytelling, Field trips, Games, Use of good Sense of humour etc. But all methods are not emerging \& innovative teaching methods. Innovations depends on the teacher that how they utilizes the instructional strategies while delivering lectures or teaching in clinical. Innovative applications should be evidence based. A teacher must see before class that-

A. Relevancy of selection of new approaches for using technology as a teaching tool

B. New insights for using positive behavior supports

C. Strategies for reaching students who are negative toward college

D. Techniques for teaching unmotivated learners

E. Special considerations for reaching economically disadvantaged students

F. Project-Based Learning Strategies 
G. Working with students in inclusive settings like lab, wards, community area etc.

H. Instructional techniques for gifted learners

I. Classroom management techniques the increase instruction time

J. Strategies that work in a common core

K. How to empower students to think critically and be creative

L. Creative, fresh, ready-to-use activities and techniques for teacher

Nursing is a profession that theoretical and practical training need to be integrated. Some of education strategies have been used to improve students' psychomotor and communication skills which are as follow:-

\section{Simulation}

Simulation is described as a strategy, not a technology to mirror, anticipate, or amplify real situations with guided experiences in a fully interactive way. In broad, simple terms a simulation is a person, device, or set of conditions which attempts to present and solve the problems authentically. Methods in clinical simulation can be used are Role play, skit, Standardized patients, Models, Three dimensional simulations like manikins, Virtual reality simulations, Computer simulations, Video interactions etc. Simulators are used to present concept and practice to nursing students in a very interactive way [7].

\section{Case base learning}

«The investigative case-based learning approach is a method of learning and teaching that gives students opportunities to direct their own learning as they explore the science underlying realistically complex situations.»

\section{Problem based learning}

Problem Based Learning (PBL) is an instructional method for active learning for nursing students to understand the concept, improve the critical thinking and develop problem solving skills. PBL is an approach that develops students' ability to critically apply the cumulative knowledge to actual clinical problems which reinforces motivation to learn, develops clinical reasoning skills, and enhance self-directed and life-long learning.

\section{Videoconferencing and web based conferencing}

By this method and technology students and educators can get connected and clear their quarries, show live demonstration across the distance. It also helps in connecting diverse student groups from different places.

E-learning: This method helps students in adaptation of different distance learning technologies for self directed, active learning and refocusing from educator to the subject through internet.
Tele Teaching: Online model of education where learner directly interacts with tutor. This is learner oriented learning which promotes discovery learning at their office or home.

Blackboard learn or web based learning: Blackboard is a Web-based learning management system (LMS) designed to support fully online courses or provide a space for face-to-face course supplementation. Blackboard provides many types of tools and features for enriching the learning experience. Learning solutions are educational delivery methods that provide people with the knowledge and skills they need to enhance performance and achieve organizational goals.

Use of Multimedia in the Classroom: Multimedia technology as an innovative teaching and learning strategy in a problem-based learning environment by giving the students a multimedia project to train them in this skill set.

Active learning classroom: Active Learning Classrooms are designed to promote the concept of "active learning" into inperson classroom environments of any size, for virtually any type of course. Active learning involves the engagement of students and educators in the learning process through collaborative classroom activities and reflection.

\section{Conclusion}

A combination of technologies \& Social media plays a critical role in this by promoting the integration of technologies, humanization of virtual interactions, and personalization of learning $[8,9]$. New technologies continue to emerge and bring with them the promise to reform and revitalize today's higher education system [10]. Globally, there has been a call for a paradigm shift, from a teacher to a learner centered approach in nursing education. After discussing these innovative and emerging technologies, very few are supported by research that the effectiveness of several of these technologies in improving student learning and achievement (e.g., Active Learning Classrooms, Simulation Technology), and most of them have not been fully evaluated and likely will need to be refined iteratively as weaknesses are identified and new challenges arise [11]. Furthermore, educators must be fully trained and incentivized to use new technologies. Nonetheless, these technologies and/ or others not yet conceptualized will surely be incorporated into health care education as it evolves to meet the many challenges of 21st-century learning.

\section{References}

1. Ruban A (2014) A Study on Innovative Teaching Learning Practices in Colleges; Conference proceedings; International conference on enhancing excellence, equity and efficiency in higher education, Chennai, India, DOI: 10.13140/2.1.4024.0322.

2. Kalaivani A (2014) Role of E-Learning in the Quality Improvement of Higher Education. IOSR Journal of Humanities and Social Science (IOSR-JHSS) 19(11): 15-17.

3. Heaslip P (2008) Critical Thinking and Nursing. Thompson Rivers University, Kamloops, Canada. 
4. Nabors K (2012) Active learning strategies in classroom teaching: Practices of associate degree nurse educators in a southern state. Department of Educational Leadership, Policy, and Technology Studies in the Graduate School of the University of Alabama, Alabama.

5. Jayalaxmi (2016) Importance of innovative teaching methods an evaluative study of traditional and modern teaching techniques-a survey. International Journal of Current Research and Modern Education 1(1)

6. Mary SS (2014) Current pedagogical teaching strategies being used by educators at the Kwazulu -Natal college of nursing campuses Across varied subjects and their views regarding Innovative methodologies. A dissertation, Department of Nursing, Durban University of Technology, South Africa.

7. Durham CF, Alden KR (2008) Enhancing Patient Safety in Nursing Education Through Patient Simulation. In: Hughes RG (Ed.), Patient
Safety and Quality: An Evidence-Based Handbook for Nurses. Agency for Healthcare Research and Quality, USA.

8. Brindley JE, Walti C, Blaschke LM (2009) Creating effective collaborative learning groups in an online environment. The International Review of Research in Open and Distance Learning 10(3).

9. Morrison D (2013) Three social trends that will influence education in 2014. online learning insights.

10. Ahalt S, Fecho K (2015) Ten Emerging Technologies for Higher Education. RENCI, University of North Carolina at Chapel Hill, USA.

11. Singh V, Kharb P (2013) A paradism shift from teaching to learning gross anatomy: meta-analysis of implications for instructional method. Journal of anatomical society of India 62(1): 84-89.

\section{Your next submission with Juniper Publishers will reach you the below assets}

- Quality Editorial service

- Swift Peer Review

- Reprints availability

- E-prints Service

- Manuscript Podcast for convenient understanding

- Global attainment for your research

- Manuscript accessibility in different formats

( Pdf, E-pub, Full Text, Audio)

- Unceasing customer service

Track the below URL for one-step submission https://juniperpublishers.com/online-submission.php 